\title{
Influence of Sports Marketing Strategies in the Promotion of Organization Products and Services in Ilorin Metropolis
}

\section{Issa Yaqub Ajeigbe}

Department of Human Kinetics and Health Education Faculty of Education, Kwara State University, Malete, Nigeria

\author{
Article History: \\ Received: 28 August 2021 \\ Accepted: 1 October 2021 \\ Published: 1 October 2021
}

\section{Keywords:}

Sports marketing, Strategies, Promotion of Organization, Products and Services

\begin{abstract}
Sport marketing remain an important aspect of global sports innovation as it is relevant to the growth of business as well as its survival. It is further prescribed as a means by which company or an organization communicate their services in a sport-oriented context. Sports marketing has been developed to promote sports events and teams as well as promotion of other products and services to consumers. Descriptive survey design was used in this study. The population comprised the sport marketers and organizations that produce and sell sport products and services to consumers totaling 54 and no sample was selected as all the marketers and organization staff were used as sampled for the study. Structured questionnaire designed in a four-point likert rating scale which was validated by experts in sports marketing and tested for reliability with coefficient result of 0.82 was used to elicit data from the respondents. Two research questions and two research hypotheses were formulated for the study. The two research questions were analysed using frequency, percentage and means score while the hypotheses were tested using independent T-test at 0.05 level of significant and funding reveals that there was no significant difference in the sport marketer perception of the influence of sport marketing strategy on the promotion of organization products as well as to produce valued products based on gender. Among the recommendations, suggested include: organization must strengthen btheir marketing strategies in order to promote their products among others
\end{abstract}

\section{How To Cite:}

Ajeigbe, I. Y. (2021). Influence of Sports Marketing Strategies in the Promotion of Organization Products and Services in Ilorin Metropolis. Indonesian Journal of Sport Management, 1(2), 128-137. https://doi.org/10.31949/ijsm.v1i2.1311

Corresponding author: Department of Human Kinetics and Health Education Faculty of Email: issa.ajeigbe@kwasu.edu.ng 


\section{INTRODUCTION}

Sport marketing is an important aspect of global sports innovation as it is relevant to the business growth as well as survival. Sport marking is prescribed further as the chance for a company or an organization to communicate their service in a sportoriented context. It notes that sports marketing has been developed to both the promotion of sports events and teams as well as promotion of other products and services in relation to sports events. Mason (1999) discussed the role of the sports products and services and customer - supporters from a business perspective, the goal is to provide business companies with strategies to promote the sports or products and services through sports events. Thus, the primary sports products can be tangible as well as intangible in nature.

Sport marketing is a recent addition with the broad concept of marketing. It is history is not well documented. However, Shilbury, Westerbeek, and Quick et. al (2009), Gray and MC Evoy (2005) and Fullerton and Merz (2008) attributes the genesis of the term sport marketing to a story in 1978 issue of the advertising Age where sport marketing was characterized as the activities of consumer and industrial product marketers who are increasingly using sport as promotional vehicle. Fullerton and Merz (2008) note that despite it is acknowledged towards the economic success of sport and non-sport organizations, there is no consensus as to what exactly is meant by sport marketing. A review of sports marketing literature noted serious inconsistencies in the definition of the sport marketing. However, most of the definitions shows that there are two thrusts of sports marketing that is, Marketing of sports and marketing through sports. Marketing of sport involves the marketing of sport goods and services directly to sport customers, advertising sports teams and events, selling tickets and writing press releases etc. while Marketing through sport involves using sports to market other consumer goods and services which may include such activities as naming right to venue, team or sport event sponsorship, product or brand endorsement by prominent sport people.

Marketing of sports includes marketing sporting events and equipment to fans and participants. This sort of marketing is intrinsic in the introduction of new sports such as action sports and innovative new sports products (Fullerton \& Merz, 2008). Marketing through sports is considered as communications media or sponsorship alternative for organizations that market consumers, and to a lesser extent enterprise product. While Marketing of sports is an approach to marketing activities and processes of marketing, goods as well as services toward sports fans and spectators. Marketing through sports means the promotion of non-sporting products and or services at sporting events and the use of players to support nonsport products and or services (Fullerton \& Merz, 2008; Ratten \& Ratten, 2011; Rundh \& Gott Fridsson, 2015; shilbury, 2009).

In general, sport marketing is characterized as a social and managerial process by which the sports managers look for obtaining what sporting companies require and desire through creating and exchanging products and benefits with people and other companies (Shilbury, 2009). Fullerton and Merz (2008) reveals that sports marketing strategy is the activity of planning and implementing processes for production, pricing, promotion and distribution of sport and products to satisfy the needs or desires of customers to achieve the organization's result. For Smith and 
Westerbeek (2003), sports Marketing must have focused on marketing of sports products as a basis for creation of revenue for sports organizations.

Sports Marketing consists of all activities designed to meet needs and wants of sports customers through exchange processes. Evans, James and Tomes (1996) describes sport marketing as the use of sports as a promotional vehicle for consumer and industrial goods and services and as the marketing of sports products, services, and events to consumers of sprorts.

The marketing strategy is defined as the marketing logic by which a business hope to create value for customers (Kotler \& Armstrong, 2010). The authors argue that this strategy include decisions about which customers to serve and how these customers will be served. Hawkins and Mother baugh (2010) explain that the basis of a sport marketing strategy is an understanding of those consumers that the business wishes to target. These authors elaborate that the sports consumers' reaction to the sports marketing strategy determines the business success or failure.

Target marketing is done by identifying the total market, then dividing it into smaller segments, selecting the most promising segments and focusing on serving and satisfying the customers or consumers in those segments (Kotler \& Armstrong, 2010). Perreault et al. (2008) asserts that a marketing strategy should begin with anticipating potential consumers' needs.

The strategic marketing of sport products and services aims at finding a competitive edge on the market by identifying the different needs in the market and doing so better than others. (McDaniel et al; 2008). Hawkins and Mothersbaugh (2010) emphasize that in order to survive in progressively competitive environment a business must provide its target consumers with more valued products than its competitors, while at the same time considering value for the consumer's perspective. This means providing superior value products requires that the sport business should anticipate and react to consumer needs more effectively than its competitors, which is the essence of a good sport marketing strategy.

At the most fundamental level, sports marketing plan or strategy embraces a general philosophy or a set of beliefs about marketing performance in an organization. It is not only sport marketers and marketing sector of sports entity that are responsible for marketing activities and processes. A marketing philosophy means putting the needs and wants of a customer - fan in the centre of decision making (Silva Mazzon, 2016). It is pertinent to include that the needs of the customer - fans must complement the objectives of the sports entities. Marketing principles involves generating a win- win exchange process for both the sport club and customer - fans, but it realizes that no one will win if customer - fans expectation is not achieved (Blumrodt, Desbordes \& Bodin, 2013). Sport marketing may be summarized as a philosophy based on some commercial strategies which involve sorne processes, a set of general rules and guidelines as well as a tools for managing customer relationship (Mastermann, 2004; Maltese \&Danglade, 2014).

Fullerton and Merz (2008) identify four domains that comprise the sports marketing environment as theme-based, product - based, alignment - based and sports-based strategies. Theme-based strategies is defined as the use of traditional marketing strategies that incorporate a sport theme into the marketing programme for non-sport products. This may involve the use of a sports-related platform to 
advertise, non-sports products (Lysias, (2014) citing (Fullerton \& Merz, 2008). The author further note that a key aspect of theme-based strategy is that the marketer efforts are not predicated upon an official relationship with any specific sports property in its effort to create the sports overlay for its marketing efforts. "Products related strategies on the other hand, are these effort to market sports products using traditional marketing strategies when the marketer has no official relationship with the sports=]] entity being used in its marketing efforts (Lysias, 2014). This may involved initiatives by marketers of sports equipment and attire who drop prices and provide incentives for the retailers. Alignment-based strategies involves marketers of non-sports products who officially align themselves with sports properties via one or more of the four forms of sponsorship e.g. Traditional sponsorships, venue naming rights, endorsements and licensing agreements. Finally, Lysias (2014) reveals that official sponsors of a sports property who are selling other sport products characterize the final domain i.e sports-based strategies. However, because of the role of sports in both the product and integration dimensions, this sports-based strategies may reflect the greatest reliance on sports-oriented initiatives.

One of the best new marketing strategies to promotes sports products is to work with influential people that have large social followings. As influential people increasingly build their own media platform and reach, brands must consider how to best pair their product offerings with the influencers that can best promote them. As it turns out, not only is this more effective than most digital advertising, the campaigns go well beyond the promotion period because prospective customers are more likely to remember the campaign since it features someone they trust and respect. For example, research was conducted by Forbes (2014) on "BMX "Flatland" Pro rider Jorge "Viki" Gomez and a fellow rider created the "BMX Plore Tour" Traveling around the world and performing acrobatics with their bikes for all to enjoy. He ensure that the tour extended through 2014 "The idea is to visit-place where BMX has never been seen before and to inspire people with new ways of expressing art and the use of bicycle, meanwhile promoting a young and healthy lifestyle. The sponsors receive brand visibility and awareness through social media, in a new and modern way for the growing market in sports, travel and fashion". The impact is that not only will Gomez be promoting the products he likes around the world, he will also cement them in the minds of his followers through social media. (Mark, 2014).

Another one was conducted on Jackie joyner-kersee, three-time Olympic gold medalist and one of the all time greatest athletes in the women's heptathlon and long jump, her concerned is about the consumption of sugary drinks that lead to obesity and unhealthy lifestyles. Kersee worked with a company emphasizing how cool it is to drink water. She focused on the positive aspect of why drinking water is so important. She utilized some of her athletic friend to post on social channel about why they drink water and share stories about how water has made a difference in their training "The impact is that imagine working with Kersee to promote nearly anything related to sport she'd moved the awareness needle and the product with it.

Since we are interested in using the popularity of sport to create compelling attention to organization products and services, what we need to do is to create the 
right product, making it a brand and promoting it with sport start with understanding the right sport marketing strategy to use. These right sport marketing strategies to use include; understanding of target audience which will give you clue on how to reach them, create a unique angle which is an excellent idea to position once brand from an unusual or unique perspective i.e. what one can do to make your brand stick in the minds of fans that come around to watch the games, lessons on sports marketing from Google home which explain to the organization how in the world do the organization complete with a device like Amazon Echo, a device that made a name for itself globally. Google home can do the selling of consumers on Google better than Amazon, create engaging content that suits your target audience by tailoring your message to suit audiences identify the best channel to reach the audience i.e social media marketing channels like Twitter, Instagram, and Facebook are the likely options or content marketing platforms like Youtube, Blogs and Press releases, build up partnerships- Brands are becoming ever data driven, hence the need for partnerships to scale up promotions and finally sponsorship which remains the top sport marketing strategy to generate quality brand (Sport managenthub.com/2019).

The following research hypotheses are generated for this study. H01: There is no significant difference in the sport marketers' perception of the influence of sports marketing strategy on the promotion of organization products based on gender. HO2: There is no significant difference in the sport marketers' perception of the influence of sports marketing strategy on the organization to produce valued products

\section{METHOD}

The study examined the influence of sports marketing strategies on the promotion of sport organization product and services in Ilorin metropolis. The research design used was a descriptive survey design. This design became important as the study involves data collection, organized, analyzed and then described as they exist without interfering with them (Aloysius 1998). The population for the study comprised the sport marketers and organizations that produce sport products in the metropolis, totaling 54 and no sample was selected as all the identified sports marketers and staff of organizations producing sports goods and services are used for the study. Structured questionnaire designed in a four-point likert rating format was used to generate data from the respondents. The questionnaire was validated by experts in the field of sports management and the reliability of the instrument was established using split half method and results were correlated using cronbach alpha to determine the coefficient result and co-efficient result of 0.71 was obtained. The research questions were analysed using frequency counts percentage and mean score while the hypotheses were tested using independent T-test at 0.05 level of significance

\section{RESULT AND DISCUSSION}

Table 1, shows the influence of sport marketing strategies on the promotion of organization products. The respondents strongly agreed with the following statements: Product related strategies are those efforts to market sport products 
(3.64), using influential people to market sport products will enhance promotion of organization product (3.56). similarly, the respondents strongly agreed with the following statements: consumers are more likely to remember the campaign since it features some influential people they trust and respect (3.31). the use of influencer as a sport marketing strategy will help to promote nearly anything related to sports and create awareness needle and the products with it (3.22). Marketing strategies will enable the organization to survive in a progressively competitive environment (3.47). sport marketing strategies will enable the organization to understand the consumer and the business wishes to target thereby promoting their products (3.38). Sports Marketing plan must embrace a general philosophy that enhances organization performance (3.40). The weighted mean is 3.43 which is a numeric indicator that sports marketing strategies influence promotion of organization products.

Table 1. The influence of sport marketing strategies on the production of organization products.

\begin{tabular}{|c|c|c|c|c|c|c|}
\hline $\mathrm{S} / \mathrm{N}$ & STATEMENTS & SA & A & D & SD & Mean \\
\hline 1 & $\begin{array}{l}\text { Product related strategies are } \\
\text { those efforts to market sport } \\
\text { products. }\end{array}$ & $41(74.5)$ & $10(18.2) 2$ & $2(3.6)$ & $2(3.6)$ & 3.64 \\
\hline 2 & $\begin{array}{l}\text { Using influential people to } \\
\text { market sport products will } \\
\text { enhance promotion of } \\
\text { organization product. }\end{array}$ & $32(58.2)$ & $22(40.0)$ & $1(1.8)$ & - & 3.56 \\
\hline 3 & $\begin{array}{l}\text { Consumers are more likely to } \\
\text { remember the campaign since } \\
\text { it features some influential } \\
\text { people they trust and respect }\end{array}$ & $22(40.0)$ & $29(52.7)$ & $3(5.5)$ & $1(1.8)$ & 3.31 \\
\hline 4 & $\begin{array}{l}\text { The use of influence as a sports } \\
\text { marketing strategy will help to } \\
\text { promote nearly anything } \\
\text { related to sport and create } \\
\text { awareness needle and the } \\
\text { product with us. }\end{array}$ & $21(38.2)$ & $26(47.3)$ & $7(12.7)$ & $1(1.8)$ & 3.22 \\
\hline 5 & $\begin{array}{l}\text { Marketing strategies will } \\
\text { enable the organization to } \\
\text { survive in a progressively } \\
\text { competitive environment }\end{array}$ & $29(52.7)$ & $23(41.8)$ & $3(5.5)$ & - & 3.47 \\
\hline 6 & $\begin{array}{l}\text { Sports marketing strategies } \\
\text { will enable the organization to } \\
\text { understand the consumers } \\
\text { and the business wishes to } \\
\text { target thereby promoting their } \\
\text { products }\end{array}$ & $26(47.3)$ & $24(43.6)$ & $5(9.1)$ & - & 3.38 \\
\hline 7 & $\begin{array}{l}\text { Sport marketing plan must } \\
\text { embrace a general philosophy } \\
\text { that enhances organization }\end{array}$ & $25(45.5)$ & $28(50.9)$ & $1(1.8)$ & $1(1.8)$ & 3.40 \\
\hline
\end{tabular}
performance 
Table 2. The influence of sports marketing strategies on the organization to produce valued products for the consumers.

\begin{tabular}{|c|c|c|c|c|c|c|}
\hline $\mathrm{S} / \mathrm{N}$ & STATEMENTS & SA & $\mathrm{A}$ & $\mathrm{D}$ & SD & MEAN \\
\hline 1 & $\begin{array}{l}\text { Marketing strategy will help the } \\
\text { organization to create value for } \\
\text { consumers }\end{array}$ & $28(50.9)$ & $19(34.5)$ & $8(14.5)$ & - & 3.36 \\
\hline 2 & $\begin{array}{l}\text { It is a technique by which business } \\
\text { organization provide its target } \\
\text { consumers with more valued } \\
\text { products than its competitors }\end{array}$ & $27(49.1)$ & $20(36.4)$ & $7(12.7)$ & $1(1.8)$ & 3.33 \\
\hline 3 & $\begin{array}{l}\text { Sponsorship which remains the top } \\
\text { sports marketing strategy will help } \\
\text { organization to generate quality } \\
\text { brand }\end{array}$ & $21(38.2)$ & $24(43.6)$ & $8(14.5)$ & $2(3.6)$ & 3.16 \\
\hline 4 & $\begin{array}{l}\text { Understanding of target audience } \\
\text { will give clue to organization to } \\
\text { reach the consumers with valued } \\
\text { products }\end{array}$ & $24(43.6)$ & $18(32.7)$ & $11(20.0)$ & $2(3.6)$ & 3.16 \\
\hline 5 & $\begin{array}{l}\text { The use of influential people to } \\
\text { market sport products will enable } \\
\text { consumers to suggest new ideals on } \\
\text { how to improve products because } \\
\text { of the trust and respect they have } \\
\text { for the consumers }\end{array}$ & $22(40.0)$ & $27(49.1)$ & $5(9.1)$ & $1(1.8)$ & 3.36 \\
\hline 6 & $\begin{array}{l}\text { The consumers' reaction to sports } \\
\text { marketing strategy determines the } \\
\text { organization success or failure }\end{array}$ & $21(38.2)$ & $23(41.8)$ & $10(18.2)$ & $1(1.8)$ & 3.16 \\
\hline 7 & $\begin{array}{l}\text { Providing supervisor value } \\
\text { products requires that the sport } \\
\text { organization should anticipate and } \\
\text { react to consumers' need more } \\
\text { effectively. }\end{array}$ & $25(45.5)$ & $24(43.6)$ & $5(9.1)$ & $1(1.8)$ & 3.33 \\
\hline \multicolumn{6}{|c|}{ Weighted Mean } & 3.27 \\
\hline
\end{tabular}

Table 2, shows the influence of sport marketing strategies on the organization to produce valued products for the consumers. The respondents strongly agreed with the following statements: Marketing strategy will help the organization to create value for consumers (3.36), it is a technique by which business organization provide the target consumers with more valued products than its competitors (3.33), sponsorship which remains the top sports marketing strategy will help organization to generate quality brand (3.16). Understanding of target audience will give clue to the organization to reach consumers with valued products (3.16). The use of influential people to market sport products will enable consumers to suggest new ideas on how to improve products because of the trust and respect they have for the consumer (3.36). the consumers reaction to sports marketing strategy 
determine the organization success or failure (3.16). Providing superior valued products requires that the sports organization should anticipate and react to consumers needs more effectively (3.33). The weighted means is 3.27 which is a numeric indicator that sports marketing strategies influence organization to produces valued products for the consumers

Table 3. The difference in the sport marketer perception of the influence sports marketing strategy on the promotion of organization product based on gender

\begin{tabular}{cccccccc}
\hline Variable & No & Means & Std & T & Df & Sig & Remark \\
\hline Male & 29 & 46.72 & 4.11 & -284 & 53 & .816 & Not significant \\
Female & 26 & 47.00 & 4.63 & & & & \\
\hline
\end{tabular}

Table 3 shows the difference in the sport marketers' perception of the influence of sports marketing strategy on the promotion of organization products based on gender $(t=284 ; \mathrm{df}=53, \mathrm{P}>0.05)$. The hypothesis is therefore not rejected in the light of the result since the significant value is greater than 0.05 .

Table 4. The difference in the sport marketers' perception of the influence of sports marketing strategy on the organization to produce valued products based on gender

\begin{tabular}{cccccccc}
\hline Variable & No & Means & Std & T & Df & Sig & Remark \\
\hline Male & 29 & 43.52 & 4.00 & -296 & 53 & .724 & Not significant \\
Female & 26 & 46.28 & 4.36 & & & & \\
\hline
\end{tabular}

Table 4 show the difference in the sport marketers' perception of the influence of sports marketing strategy on the organization to produce valued products based on gender $(t=-296 ; d f=53, P>0.05)$. The hypothesis is therefore not rejected in the light of the result since the significant value is greater than 0.05 .

\section{Discussion of Finding}

The result of (H01) which reveals that there was no significant difference in the sports marketers' perception of the influence of sport marketing strategy on the promotion of organization products based on gender is line with the submission of Gray and McEvoy (2005) and Fullerton and Merz (2008) who both attributed the genesis of the term sports marketing to a story of 1978 issue of the advertising Age where sports Marketing was characterized as the activities of consumer and industrial product marketers who are increasingly using sports as promotional vehicle. In addition, Fullerton and Merz (2008) reveals that sports marketing strategy is the activity of planning and implementing processes for production, pricing, promotion and distribution of sport products to satisfy the needs or desires of customers to achieve the organization's results.

In addition, the result of hypothesis two (H02) also reveals that there was no significant difference in the sport marketers' perception of the influence of sports marketing strategy on the organization to produce valued products based on gen der is in line with the submission of Kotler and Armstrong (2010) when they described marketing strategy as the marketing logic by which a business hopes to create value for customers. In addition, Hawkins and Morthersbaugh (2010) emphasise that in order to survive in a progressively competitive environment, a business must provide its target consumers with more valued products than its competitors, while 
at the same time considering value for the consumer's needs more effectively than its competitors, which is the essence of a good sports marketing strategy.

\section{CONCLUSION}

The following conclusion were drawn from the findings of this study. The respondents (Male and Female) are the same in their opinion that sports marketing strategy influence the promotion of organization products. Also, respondents (Male and Female) are not different in their perception about the influence of sports marketing strategy on the organization to produce valued products for the consumers.

The following recommendations were suggested based on the findings of the study. The organization must strengthen their marketing strategies the more in order to promote their products. Organization should employ the best new strategy by working with influential people that have large social followings to promotes their products. Additional efforts should be put in place by organization to ensure more marketing strategy to produce valued products and services for the customers in order to edge their competitors.

\section{ACKNOWLEDGEMENT}

This study was not receive any support. There is no conflict of interest in this study.

\section{REFERENCES}

Blumrodt, J., Desbordes, M. \& Bodin, D. (2013). Professional football clubs and corporate social responsibility. Sport Business and Management,3(3),205-225. https://doi.org/10.1108/SBM-04-2011-0050

Evans, A., james, T. \& Tomes, A. (1996). Marketing in UK Sport associations. The Services Industries Journal, 16 (2), 207-222

Fullerton, S. \& Merz, G.R. (2008). The four domains of sport Marketing: A conceptual frame work. Sports Marketing Quarterly, 17 (2), 90 - 108.

Gray, D., \& Mc Evoy (2005). Sport Marketing Strategies and Tactics. In Park House, B (Ed). The management of Sport: its Foundations and Application, Mc Graw-House Inc, New York.

Hawkins,D. I. \& Mothersbaugh, (2010). Consumer behavior: building marketing strategy (Book, 2010) [Worldcat.org] https://www.worldcat.org

Kotler, P., \& Armstrong, G (2010). Principle of Marketing, (14th ed.). Prentice Hall New Jersey.

Maltese, L., of Danglade, J.P. (2014). Marketing du sport et evenementiel sportif. Paris: Dunod.

Mark Fidelman http://www.forbes.com/sites/markfidelman/2014/02/19/16-powerfulsport-marketingpromotion-that-are-better-than-google/\#157/age6603d

McDaniel, K. (2008). Against composition as identity-McDaniel-2008-Analysis-Wiley Online Library. 
Mason, D.S. (1999). What is the sports production and who buys it? The marketing of professional sport leagues. European Journal of Marketing 33 (3/4), 402-418. http://doi.org/10.1108/03090569910253251

Masterman, G. (2004). Strategic Sports even management: An International approach. London, UK: Elsevier Butterworth-Heinemann.

Parreault, B. (2008). Basic Marketing: A Global Managerial Approach// Request PDFResearch Gate.

Ratten, V. \& Ratten, H. (2011). International Sports Marketing: Practical and Future research implications. Journal of Business of Industrial Marketing, 26 (8), 614 - 620. http://doi.org/10.1108/08858621111179889

Rundh, B of Gottfridsson, P. (2015). Delivering sports events: the arena concept in sports from network perspective. Journal of business of Industrial Marketing, 30 (7). 785794. http://doi.org/10.1108/JBIM-06-2013-0131

Shibury, D. (2009). Sport Management series (3rd ed). Sydney: Allen of Unwin

Shibury, D., Westerbeek, H., Quick, S., \& Funk, D. (2009). Strategic Sport Marketing (3 ${ }^{\text {rd }}$ ed.). Allen \& Unwin, CrowsNest: (Australia).

Silva, E.C. of Mazzon, J.A. (2016). Delivering Social Marketing Plan for for Health promotion. International Journal of Public Admmistration, 39 (8), 1-10. http://dx.doi.org/10.1080/01900692.2015.1023447

Smith, A.m \& Westerbeek, H. (2003). Sport Business in the global market place. New York: Palgrave, Macmillan.

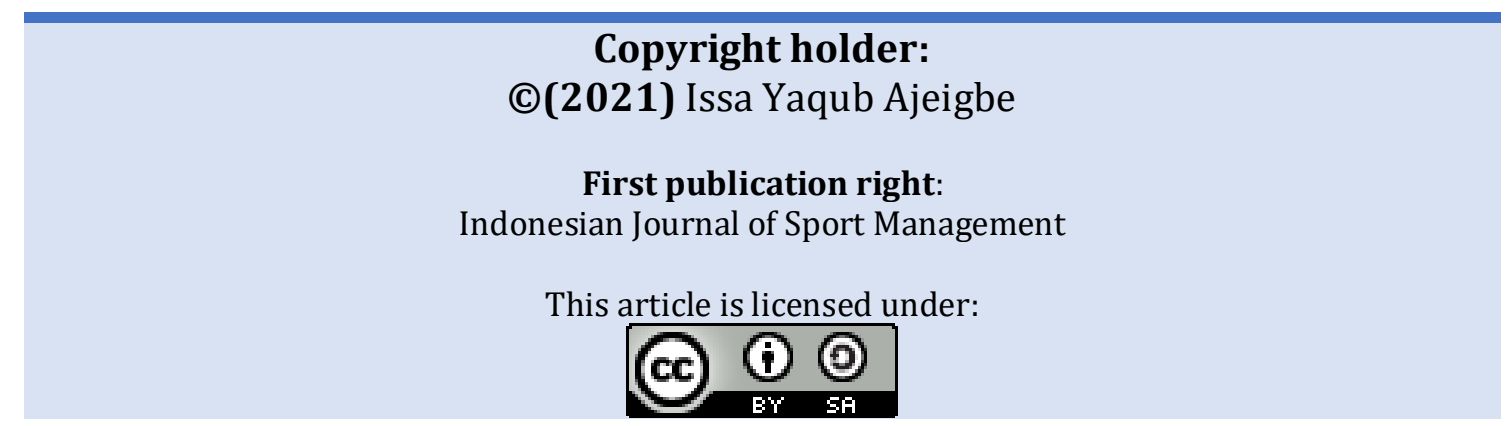

